\title{
外来透析患者における内服薬の理解度に関する統計学的解析†
}

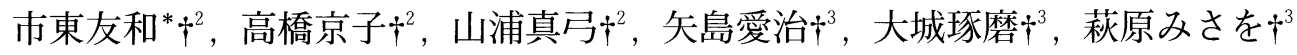 \\ 医療法人社団大坪会東和病院薬骫部 $\dagger^{2}$, 同透析室 $\dagger^{3}$
}

\section{Statistical Analysis Regarding the Knowledge of Medication on Chronic Hemodialysis Outpatients $\dagger$}

\author{
Tomokazu Shito ${ }^{*}{ }^{2}$, Kyoko Takahashi $\dagger^{2}$, Mayumi Yamaura $\dagger^{2}$, Aiji Yajima $\dagger^{3}$, \\ Takuma Ohshiro $\dagger^{3}$ and Misao Hagiwara $\dagger^{3}$ \\ Department of Pharmacy, Towa Hospital $\dagger^{2}$ \\ Dialysis Unit, Towa Hospital $\dagger^{3}$
}

$\left[\begin{array}{l}\text { Received October 16, } 2002 \\ \text { Accepted May 18, } 2003\end{array}\right]$

Chronic hemodialysis outpatients take various medicines for a long time, and require 3 or 4 hours for one hemodialysis treatment. Therefore, we should give pertinent information efficiency in order to maintain their quality of life. The purpose of this study was to investigate the knowledge of medication statistically on chronic hemodialysis outpatients from the pharmacist's point of view and to inspect the capable instruction in medication.

The 63 chronic hemodialysis outpatients, who had received instructions in medication at Towa hospital during February and March 2002, were selected by random sampling. For them, we carried out the questionnaire by interview and inquiry into medical reports. We converted the answers to the score on knowledge, and made a correlation analysis between the score and the patient's background. In addition, we made a simple regression analysis, using the one way analysis of variance (ANOVA), and the Tukey-Kramer test.

We obtained the following results $: 1$. The score on knowledge of medication was $11.2 \pm 4.6$ marks out of 25. 2. Regarding the score on knowledge of medication, the group in the age younger than 60 moreover in the duration of hemodialisis above 5 years $(15.7 \pm 2.5$ marks $)$ and the group in non-diabetes mellitus $(12.3 \pm 4.4$ marks) were significantly higher than in the other groups. 3. $25.4 \%$ of all patients understood about side effects, $14.3 \%$ worried about interactions with some medicines, and $58.7 \%$ had made mistakes in medication one or more times.

In the light of these results, we propose that we can infer the knowledge of medication from the background of patient, such as age, the duration of hemodialysis, disease, and we can prepare materials based on the ability to understand their medication for each patient. It is also beneficial for increasing efficiency to standardize method and points of instruction, because we will be able to use more exact information even for new patient and thus make a plan of the instruction in a timely manner for such patients.

Keywords — statistical analysis, chronic hemodialysis outpatient, instruction in medication, questionnaire, inquiry into medical report.

$\dagger^{1}$ 本論文の要旨は，第47回日本透析医学会(東京，2002年 7 月)および第32回関東ブロック学術大会(横浜，2002年 8 月)に おいて発表した.

$\dagger^{2,3}$ 足立区東和 4-7-10;4-7-10, Towa, Adachi-ku, Tokyo, 120-0003 Japan 


\section{緒言}

近年，慢性透析患者(以下，透析患者と略す) は206, 134 人 $(2000$ 年 12 月 31 日現在，前年比 $+8,921$ 人) と増加傾向 にあり ${ }^{11}$ ，透析医療の発展により透析期間が長期化して いるため，患者の多くは合併症の予防と治療を目的とし て，多種類の薬剂を長期間服用することが不可欠であ る2). それに加え，透析日に応じた用法・用量の変更な ど服用方法が複雑になっている3.

したがって, 透析患者に対する薬剤管理指導業務では, 用法・用量とあわせて薬剤に関する正しい知識を身につ けさせることが，薬物治療の効果を高める上で重要な役 割を担っている。また，透析治療には 1 回 $3 \sim 4$ 時間か かり，患者の QOL 維持を目的とした指導時間の短縮を 考慮しなければならない. そのため, 患者の理解力に適 した薬剤情報を提供し，より効率的な服薬指導を実施す る必要がある。

これまでに，透析患者を対象として実施されたアン ケート調査では, 文書による薬剂情報提供 ${ }^{4)}$, 服薬指導5) の有用性, 服薬状況の実態 ${ }^{6-9)}$, 処方薬剂の理解度 ${ }^{10)}$,

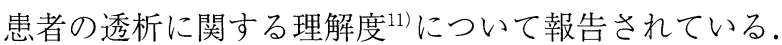
しかしながら，これらの研究は内服薬に関するアンケー 卜結果の集計，あるいは内服薬以外の内容に着目した統 計学的検討にとどまっており，外来透析患者における内 服薬の理解度について，薬剂師の視点から統計学的に解 析を加えた検討はなされていない。

そこで本研究では, 効率的かつ積極的な服薬指導方法 の確立に向けて，内服薬の理解度を統計学的に解析し， 外来透析患者における服薬指導の現状と今後の服薬指導 の方向性について検討を行った。

\section{方法}

\section{1. 東和病院における服薬指導内容}

当院薬剂部では平成 7 年 12 月から外来透析患者に対し て，定期処方 14 日分の配薬を行うと同時に，1 人あたり 月 2 回の服薬指導を透析時間内に実施している.当院は すべて院内処方であり，必要な患者に対しては 1 包化調 凨を行っている。 また，透析導入後の服用方法は特殊な 薬剂を除き，すべて炭酸カルシウム製剤にあわせて食直 後の服用として，用法の簡素化を図っている，薬剤の説 明は商品名, 薬効, 注意事項 (主に副作用)などを記載し た文書を各々の薬袋に同包し，処方変更のある患者には 口頭でも薬剤の情報提供を行っている。

\section{2. 調査期間および対象患者の設定}

平成14年 2 月 1 日から 3 月 31 日までの間に当院透析室 を受診した全透析患者105名のうち服薬指導対象患者99 名から, 乱数表を用いて無作為に抽出した63名を対象と した。

\section{3. 調查方法}

本研究では，内服薬の理解度に影響を与える要因を検 討するために，当院で作成した面談式のアンケート

(Fig. 1 ) およびカルテ調査を行った.

アンケート全 6 項目のうち問 1 , 問 2 , 問 5 の 3 項目 に関する回答を独自に点数化し, 理解度点として合計 25 点満点で評価した。点数配分は以下のとおり設定した。 問 1 は処方頻度の高い薬剂から順に (1) 降圧剂, (2)リン 吸着剂，(3)ビタミン D 製剂，(4)下剂，(5) 睡眠導入剂, (6) 利尿剂, (7) 尿酸降下剂と優先順位をつけ, 処方薬剤 の中から上位より 5 種類を選び出し，それぞれの薬剤に 対して服用目的の理解を 1 点，用法・用量の理解を 1 点 として合計10点とした。問 2 は透析日および非透析日に おける服用方法の理解を 5 点，食直後に服用する理由を 5 点として合計10点とした。問 5 は薬を飲み忘れた時, 食事を摂らなかった時の対処方法のうちいずれかを理解 していれば 5 点とした。

さらに, 問 3 : 副作用の理解, 問 4 : 飲み合わせの疑 問，問 6 : 飲み忘れの原因の 3 項目について集計を行っ た.カルテからは年齢, 性別, 透析歴, 原疾患 (糖尿病, 非糖尿病)，処方薬剤数の 5 項目を調査した。本調査は アンケート調査員 2 名, カルテ調査員 1 名, 解析者 1 名 で実施した。

\section{4. 統計解析}

調査項目に対して記述統計を算出し，データの要約を 行った.データは, 平均值士標準偏差 (mean \pm S.D.) で 示す，年歯令，透析歴，原疾患，性別，処方薬剂数，理解 度点の 6 項目に対して，各項目間の相互的な関連性を調 ベるために，相関分析 (Correlation Analysis)を行った。 理解度点と年齢および透析歴との関係には直線回帰分析 (Simple Regression Analysis)を用いた。また，年齢・透 析歴および原疾患の 2 項目が理解度点に与える影響を要 因配置分散分析 (ANOVA) により検討し，有意な差を 示した要因に対して多重比較検定 (Tukey-Kramer Test) を行った。すべての解析は Stat View for Macintosh Ver. 5.0 で行い, $\mathrm{p}<0.05$ (両側検定)をもって有意と判定し た。 
[問 1] O○の薬はなぜ服用しなければならないのか, 目的は分かりますか.

また，用法用量は覚えていますか（処方薬剤のうち上位 5 種について）

<薬の必要性・作用 $>$ 【10点】

○ 服用の必要性＼cjkstart感じている・感じていない

(1) 降 圧剂服用目的 / 用法・用量

(2)リン吸着剂服用目的 $/$ 用法・用量

(3) ビタミンD製剂服用目的 $/$ 用法・用量

(4) 下 剂服用目的 $/$ 用法・用量

(5) 睡眠 導入剂服用目的 $/$ 用法・用量

(6) 利 尿 剂 服用目的 $/$ 用法・用量

(7) 尿酸降下剂服用目的 $/$ 用法・用量

[問 2] 透析日に薬の量や飲み方を変えたり，食直後に薬を服用したり

するのはなぜだと思いますか.

$<$ 服用方法 $>$ 【10 点】

・透析をすると血圧が下がるため・胃に負担をかけないため

・透析をすると薬が除去されるため・理由はわからない

・食事と混ざる必要があるため・その他

[問 3］現在服用中の薬の副作用は覚えていますか.

<副作用 $>$

- A C E 阻害剤の咳

・降圧剂の頭痛, めまい

・パナルジンの出血傾向, 肝障害

・高脂血症剂の筋肉痛, だるさ

[問 4] 現在服用中の薬で, 飲みあわせに気をつけているものはありますか. また，普段気をつけている事はありますか，〈相互作用・飲みあわせ >

有・グレープフルーツジュース・制酸剂 ／ 無

・他の薬を飲む時は医師や薬剤師に相談する

[問 5] 薬を飲み忘れた時, 食事を摂らなかった時の,

薬の服用はどうしていますか

・対処方法の理解 : 有 (

・飲み忘れ: 有 (薬郕 :

[問 6] なぜ飲み忘れてしまうのですか

・仕事の都合

・食生活が不規則

・服薬の不安 - 外出時の不携帯
＜飲み忘れの対処法 $>$ 【5点】

) $/$ 無

) $/$ 無

＜飲み忘れの原因 $>$

・その他

Fig. 1. 面談式アンケート

結

果

\section{1. 当院における理解度点およびカルテ調査の結果}

理解度点は25点満点中平均 $11.2 \pm 4.6$ 点であり, 全体 的に低い傾向にあった。また，平均年齢61.8土10.3歳， 男性37名, 女性 26 名, 平均透析歴 $7.1 \pm 6.2$ 年, 糖尿病 15 名, 糖尿病以外 48 名, 平均処方薬剂数 $9.1 \pm 2.6$ 郕であっ た (Table 1).
Table 1. 理解度点およびカルテ調査結果

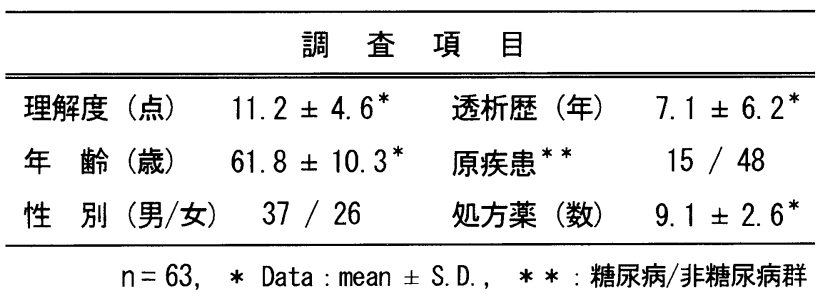




\section{2. 統計学的解析から得た理解度に関与する要因}

1) 相関分析 (Correlation Analysis)による結果

理解度点との関連性は年齢 $(\mathrm{r}=-0.58: \mathrm{p}<0.001)$, 透析歴 $(\mathrm{r}=0.45: \mathrm{p}<0.001)$, 原疾患 $(\mathrm{r}=-0.38: \mathrm{p}<$ 0.001) それぞれに認められ, 性別 $(r=-0.06: p=$ $0.704)$, 処方薬剤数 $(\mathrm{r}=-0.24: \mathrm{p}=0.058)$ には認めら れなかった。 また，年齢と透析歴 $(\mathrm{r}=-0.31: \mathrm{p}<0.05)$ の間に関連性が示されたため, 年齢・透析歴をあわせて 1 項目として取り扱った(Table 2).

2 ) 直線回帰分析 (Simple Regression Analysis)による 結果

理解度点と年齢 $(\mathrm{p}<0.001)$ および理解度点と透析歴 $(\mathrm{p}$ $<0.001)$ で有意な回帰を得た。決定係数 $R^{2}$ は年齢 $R^{2}=$ 0.34 , 透析歴 $R^{2}=0.21$ であり, 理解度点の得点変化は $34 \%$ が年齢に，21\%が透析歴に依存していた。したがっ て，この回帰は有用であると判断した(Fig. 2-1，2$2)$.

3 ) 要因配置分散分析 (ANOVA)による結果

年齢 - 透析歴 $(\mathrm{p}=0.015)$ ，原疾患 $(\mathrm{p}=0.002)$ ，年齢 透析歴/原疾患 $(p=0.788)$ の各々と理解度点の関連を解 析した結果，年齢・透析歴および原疾患の 2 項目が理解 度点に有意な影響を与えていた。また，その 2 項目間の 交互作用は認められなかったことから, 年齢・透析歴と 原疾患は互いに理解度点を変化させるような影響を与え ず，独立した要因として個別に取り扱うことが可能であ ると確認された。したがって，この 2 項目に対して多重 比較検定が実行可能と判断した.

4 ) 多重比較検定 (Tukey-Kramer Test)による結果 原疾患の違いにより, 糖尿病群 $(7.8 \pm 3.5$ 点) と非糖尿 病群 $(12.3 \pm 4.4$ 点)を比較した結果, 非糖尿病群の方が 理解度点が有意に高かった $(\mathrm{p}<0.001)($ Fig. 3-1)。ま た，年齢・透析歴に関して年齢60歳，透析歴 5 年を基準 とし A 群 : 年齢60歳以上かつ透析歴 5 年未満, B 群 : 年齢60歳未満かつ透析歴 5 年未満, $\mathrm{C}$ 群 : 年齢60歳以上 かつ透析歴 5 年以上, D 群 : 年齢60歳未満かつ透析歴 5

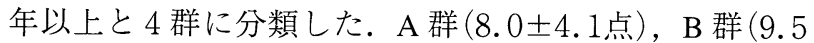
\pm 3.1 点), C 群 (10.1土4.3点) と比較した結果, D 群

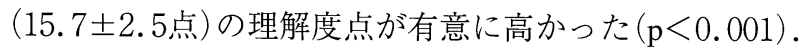
また, $\mathrm{A}$ 群， $\mathrm{B}$ 群， $\mathrm{C}$ 群の各々の群間には有意な差はみ られなかった(Fig. 3-2).

\section{3. アンケートから得た現在の薬物治療に対する認識}

アンケートの結果, 内服薬の必要性を感じている患者 は84.1\%，初期症状を含めた主な副作用を理解してい る患者は $25.4 \%$ ，飲み合わせに疑問を持つ患者は 14.3 \%であった。飲み忘れの経験がある患者は $58.7 \%$ あ
Table 2. 相関分析による調査 6 項目の相互的な関連性

\begin{tabular}{|c|c|c|c|}
\hline 年 齢 & $\mathrm{R}$ & P值 & $95 \% \mathrm{CI}$ \\
\hline 理解度点 - 年 齢 & -0.58 & $0.001^{*}$ & $-0.73 \sim-0.39$ \\
\hline 理解度点・透析歴 & 0.45 & $0.001^{*}$ & $0.23 \sim 0.61$ \\
\hline 理解度点 - 原疾患 & -0.38 & $0.001^{*}$ & $-0.60 \sim-0.21$ \\
\hline 理解度点・性＼cjkstart別 & -0.06 & 0.704 & $-0.30 \sim 0.20$ \\
\hline 理解度点·薬剂数 & -0.24 & 0.058 & $-0.47 \sim 0.03$ \\
\hline 原疾患・年＼cjkstart齢 & 0.13 & 0.320 & $-0.12 \sim 0.36$ \\
\hline 原疾患·透析歴 & -0.26 & 0.107 & $-0.48 \sim 0.08$ \\
\hline 原疾患 - 性 別 & 0.14 & 0.286 & $-0.12 \sim 0.37$ \\
\hline 原疾患 - 薬剤数 & 0.15 & 0.251 & $-0.10 \sim 0.38$ \\
\hline 年 齢- 透析歴 & -0.31 & $0.038^{*}$ & $-0.43 \sim-0.10$ \\
\hline 年 齢- 性 別 & -0.02 & 0.121 & $-0.26 \sim 0.23$ \\
\hline
\end{tabular}

$\mathrm{R}:$ 相関係数， $95 \% \mathrm{CI}: 95 \%$ 信頼区間， $* \mathrm{p}<0.05$

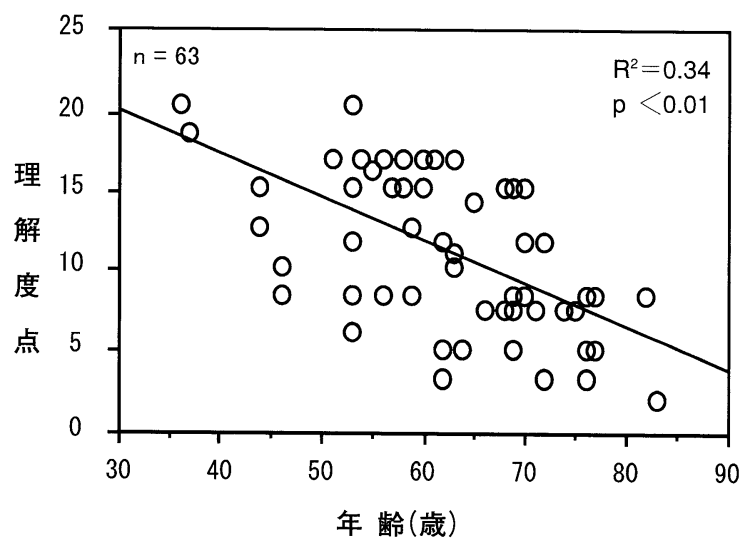

Fig. 2-1．直線回帰分析による理解度点と年齢の関係

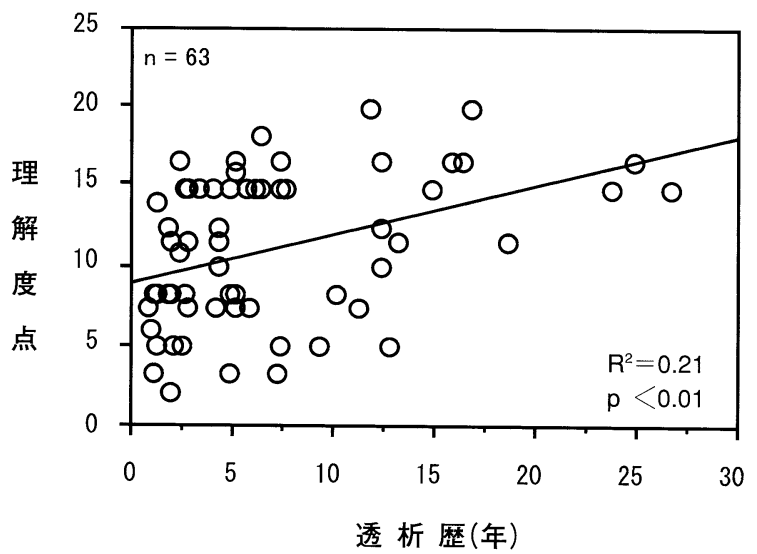

Fig. 2-2. 直線回帰分析による理解度点と透析歴の関係

り，原因の多くは外出時不携帯 $70.3 \%$, 次いで仕事の都 合 $18.9 \%$ ，不規則な生活5.4\%であった(Fig. 4-1, 4$2)$. 
536

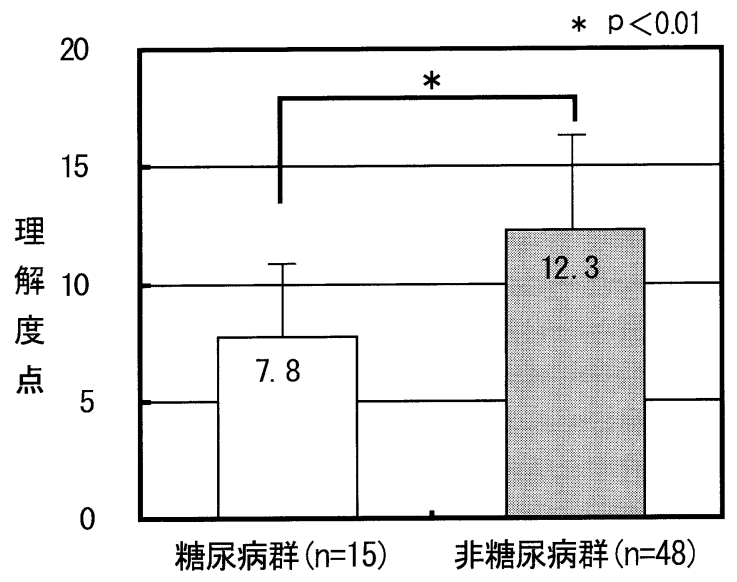

Fig. 3-1. Tukey-Kramer Test による理解度点 と原疾患の関係

* $\mathrm{p}<0.01$ D群 vs A群, B群, C群 ( $\mathrm{n}=63)$

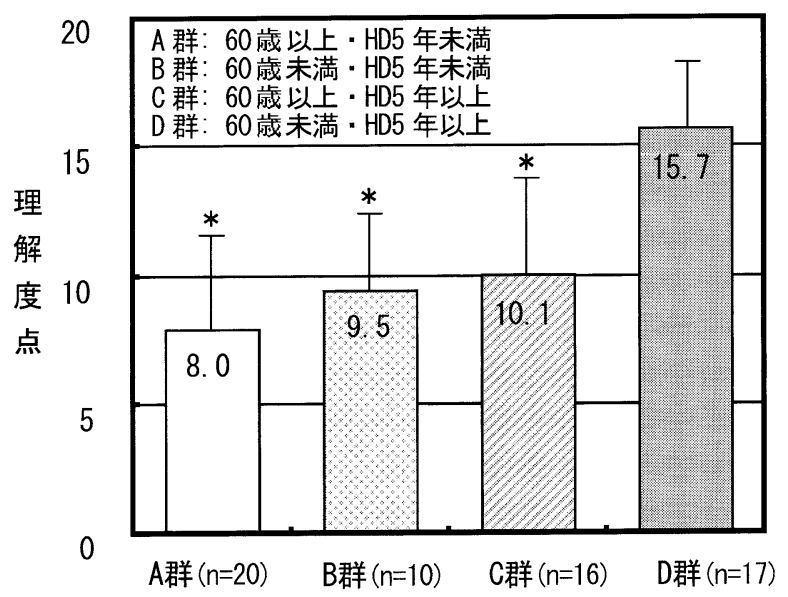

Fig.3-2. Tukey-Kramer Testによる理解度 点と年齢・透析歴の関係

\section{考察}

\section{1. 統計学的解析から推察される今後の服薬指導方法}

今回の解析の結果, 理解度点と年齢, 透析歴, 原疾患 との間に関連性があり, 理解度点と性別, 処方薬剤数の 間には，関連性がなかった。さらに検討を加えたとこ ろ, 年齢60歳未満かつ透析歴 5 年以上の群掞よび非糖尿 病群は, 他群と比較して理解度点が有意に高かった。

当院は平均年齢61.8 10.3 歳と高齢者の占める割合が 多く, 薬剤の区別・判断するのが難しいという理由から 1 包化調剂を希望する患者も63名中 10 名 (15.9\%)いた. また，内服薬の必要性を感じている患者は全体の $84.1 \%$ であり, 服薬の必要性は認識しているが, 理解度点は平 均11.2 24.6 点と全体的に低い傾向にあった。 以上より,

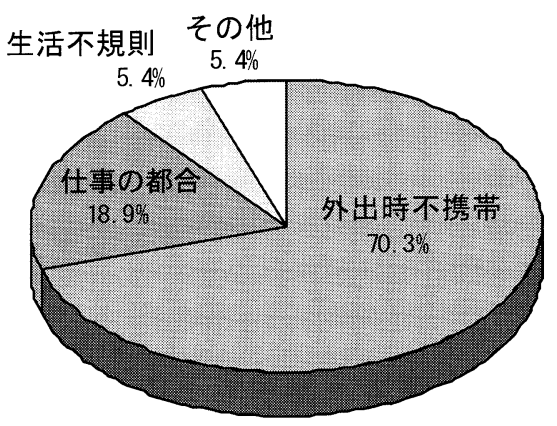

Fig.4-2. 飲み忘れの原因 $(\mathrm{n}=37)$

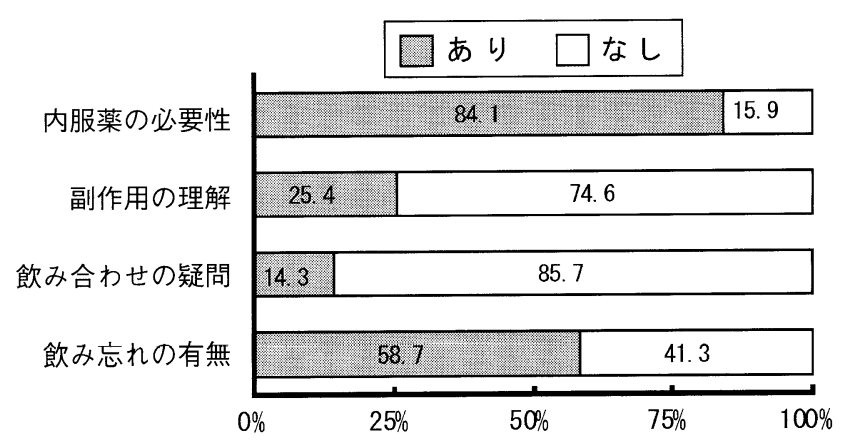

Fig.4-1.アンケートによる結果 $(\mathrm{n}=63)$

年齢による内服薬の理解度には加齢に伴う認識力, 記憶 力の低下が影響する ${ }^{12)}$ と推察した。したがって，口頭お よび文書による情報提供のみでは内服薬の用法・用量, 薬効などの理解が困難であると考えられるため, 川端 $ら^{13)}$ ，佐多ら ${ }^{14)}$ の報告をもとに，具体的な説明を平易な 表現で示した「写真付き薬剤情報提供書」を個別に配布 し，写真から内服薬の判別ができ，反復して見ることに よって必要な知識を身につけられるように工夫した。

また，透析歴の短い患者 ( 5 年末満)の理解度点は低い 傾向にあった，要因として，透析導入前後で処方内容が 大きく変更されるため ${ }^{3)}$, 透析導入後早期には用法・用 量を覚えていないが, 透析治療に伴う習慣として内服薬 の用法・用量を覚える患者が多いと推察した。ささらに, 透析歴が長い場合でも用法以外のことを知らない, 正確 に理解していない患者もいるため，習慣で覚えるのでは なく積極的に覚えさせることを目的とした服薬指導が必 要であり, 透析導入後早期に服薬指導を行うことは, 理 解度を高める上で重要と考えた。

原疾患別に見ると, 全体の理解度点は平均 $11.2 \pm 4.6$ 点, 糖尿病群では平均 $7.8 \pm 3.5$ 点と特に低かった. 本研 究から糖尿病合併患者の理解度点が低い原因について判 断はできないが，相関分析では原疾患と処方薬郕数との 
間には，関連性がないと示唆された。このように，透析 下において糖尿病を原疾患にもつ患者は, 処方薬剤数が 多いという理由ではなく, 薬物治療に対する認識が不十 分なために理解度が低いのではないかと推測した。した がって, 今回は工藤ら ${ }^{15)}$ の報告をもとに, 糖尿病患者に は透析・薬物治療に関する患者向けパンフレットを用い てロ頭で説明するなど，視覚的にも容易に理解し得る工 夫が有効と考えた。なお, 今回の対象糖尿病患者 15 名の うち, 糖尿病性網膜症・神経症の患者が 5 名 (33.3\%)い るため, 視力低下, 手指等の障害のある患者に対しては 1 包化調剂, 家族 - 介護者への指導などの併用を考慮し ていくこととした.

また, 理解度点と平均処方薬剤数については, 統計学 的に有意な関連は認められなかったが $(r=-0.24: \mathrm{p}=$ $0.058)$, 全体で平均 $9.1 \pm 2.6$ 剂と多いため, 吉岡ら ${ }^{16)}$, 足立ら ${ }^{17)}$ の報告をもとに一包化, お薬手帳などを活用し た，「正確な服用」を日的とする指導が適していると考 えた。

\section{2. アンケートから推察される今後の服薬指導方法}

現在, 注意事項や副作用などを記載した文書を各々の 薬袋に同包しているが，初期症状を含めた主な副作用を 理解できていない患者が，全体の74.6\%を占めており， また，アンケートの回答として「医師による処方薬であ るため, 副作用は心配していない」という意見も多くみ られた，薬剤による副作用の初期症状を患者自身が発見 することは，副作用を最小限に抑える有効な手段の 1 つ であり，薬剤の主作用と関連のない症状が現れることも 多いため, 高頻度・重大な副作用とともに長期服用に伴 う副作用, 自覚症状についても, 文書とあわせて口頭で 十分な説明を実施する必要がある。

飲みあわせについては, 患者の知識・関心の状況を知 る目的で調査を行った，飲み合わせに疑問をもっている 患者は $14.3 \%$ ありり,さらにアンケート時の面談から 「飲み合わせ」の意味そのものが正しく理解できていな いと示唆された. 特に透析患者の薬物治療は日常の自己 管理が血圧のコントロール，合併症の予防に直結するた め, 内服薬に対する「正確な知識」は薬物治療効果の向 上に有用である。このことから，当院の処方薬だけでな く, 他院および他科による処方薬, 市販薬, サプリメン ト，食品などを含めた相互作用について，併用してはい けない理由を具体的に明示していかなければならないと 考えた。

飲み忘れの経験がある患者 $58.7 \%$ のち外出時不携帯 が70.3\%を占めていた，その原因として合併症予防の重 要性, 継続的な服用の必要性が十分に理解できていない
可能性があり，これらの指導とともに飲み忘れの対処法 を示し，服薬に対する意識の向上を図っていく必要があ る.

このような現状から，初期症状を含めた主な副作用， 飲みあわせについては関心が薄く，文書を同包するだけ では十分な理解が得られないと示唆された。したがっ て, 薬物治療の一般的な知識に関する服薬指導は服薬開 始後早期に実施すること，さらに文書だけではなく薬剤 師からの積極的な面談指導が不可欠であると考えた。そ の手段として集団指導，情報誌作成などを検討してい る.

\section{3. 本研究から推察される今後の服薬指導の方向性}

このように本研究から, 年龄・透析歴, 糖尿病という $2 つ の$ 要因が理解度に影響を与えることが示された。こ れまでに, 透析患者に対する教育指導内容の理解度調査 として, 理解度は加齢により低下し, 透析経験年数に 伴って高くなるという報告 ${ }^{11,18)}$ また, 糖尿病群の方が非 糖尿病群に比べて内服薬に対する理解が低いという報 告 ${ }^{19)}$ がある. 本研究の結果は, これらの報告とも一致し ていた。したがって, 年齢・透析歴, 原疾患から内服薬 の理解度を推測し, 理解度に応じた指導方法をあらかじ め準備することが可能となる。このように指導方法, 要 点の標準化を行うことは, 新規患者や初回服薬指導に対 しても，より的確な情報提供ができると同時に，服薬指 導の方向性を早期に把握することができるため, 効率化 という点でも有益である.

本研究で示すように，アンケートに加えて統計学的な 解析を行うことは効率的な服薬指導の方向性を把握する 上で, 有効な検討手段になり得ると認識している.今 後, 本研究に基づいた服薬指導を実施し, その有用性を 再検討していきたいと考えている。

\section{引用文献}

1) 中井滋, 新里高弘, 佐中孜, 菊池健次郎, 北岡建 樹, 篠田俊雄, 山崎親雄, 坂井瑠実, 大森浩之, 守田治, 井関邦敏, 久保和雄, 田部井薰, 政金生 人, 伏見清秀, 和田篤志, 三和奈緒子, 秋葉隆, わが国の慢性透析療法の現況, 日本透析医学会雑 誌, 35, 1-28(2002).

2）田中昭人, 鈴木晃, 溝口淳子, 杉江八江子, 杉村 みゆき, 透析患者に打ける服薬実態調査, 医薬 ジャーナル， 11，2203-2209(1983).

3）南智, 見崎芳枝, 森典子, 透析患者に対する薬剂管 理指導, 医薬ジャーナル，37，2200-2206(2001).

4）早坂昭一, 森正典, 三浦より子, 松本健司, 遊佐 洋子, 西和哉, 阿部浩幸, 勝又哲夫, 我妻仁, 透 析患者への薬剂情報提供に関するアンケート調 
医療薬学 Vol. 29,No. 4 (2003)

538

査，石巻赤十字病院誌，9， 64-67(2001).

5）北島恵子，八尾順夫，竹内秀，香月英男，中西功, 当院腎臓内科に扮ける薬剂師の活動と透析患者に 対する服薬指導について，日病薬誌，30，67-72 (1994).

6）窒田久美子，北原久江，飯田洋子，奥誠子，神戸 あけみ, 湯本三和子, 野沢洋子, 堀見博之, 黒巣 恵美，柳場悟，浅野泰，外来透析患者の服薬状況 と服薬指導の必要性一院外処方に扮ける服薬状況 のアンケート調査を通して, 日本透析医学会雑誌, 34, 873(2001).

7）柳澤裕子, 中司千恵, 吉田未来，中村章子, 江藤 りか, 坂田英雄, 宮崎正信, 橋口純一郎, 船越哲, 外来透析患者の服薬実態調査, 日本透析医学会雑 誌，34，761(2001).

8）前沢哲也，角田陽子，木本成昭，当院における透 析患者の服薬に関する意識と実態調査, 長野県透 析研究会雑誌, 20, 67-69(1997).

9）都築泉, 井上智恵子, 浅越泉, 血液透析患者の服 薬実態と問題点, 医薬ジャーナル，22，767-773 (1986).

10）山谷明正, 林誠, 能村凉子, 森行雄, 鈴木達男, 透析患者のコンプライアンスと服薬理解度に関す る調査, 日病薬誌, 38, 993-995(2002).

11）西村由佳, 松浦誠子, 松葉麗久子, 野中嘉代子, 石倉丈子, 村田智博, 井上実千代，小薮助成，当 透析センターにおける患者の透析に関する理解 度，日本透析医学会雑誌，34，759(2001).

12）横出正之, 北徹, 加齢と疾患, 日薬誌, 54, 16071610(2002).
13）川端奈緒美, 西村久雄, 直良浩司, 平野栄作, 岩 本喜久生, わかりやすい薬剂情報文書の作成と患 者からの評価, 医療薬学, 27, 598-604(2001).

14）佐多照正, 岩下佳敬, 辻夏織, 中尾承司, 本田香 奈恵, 井八下陽子, 中野理美子, 本屋敏郎, 山田 勝士, 高齢者に対する服薬指導の工夫とその成果 一写真付き薬剤情報文書による服薬指導の効果 一, 日病薬誌，36，907-909(2000).

15）工藤正純，長谷川晴子，菅原和信，当院における 糖尿病教室での薬郕師による指導方法と患者から の評価，日病薬誌，35，949-953(1999).

16）吉岡三郎, 北本亜紀, 金澤佐織, 岡本成史, 横田 淳子, 尾木恭子, 宮野望, 小野川雅英, 增井寿, 京谷庄二郎, 西岡豊, 高知医科大学病院における 一包化調剂に対する外来患者意識調查と調剂過誤 に与える影響, 医療薬学, 27, 356-362 (2001).

17）足立哲夫, 丹羽孝司, 田頭正至, 窐田傑文, 鎌田 久代, 原宏和, 平野和行, 岐阜薬科大学附属薬局 に抢ける「㧍薬手帳」の利用状況, 医療薬学, 28, 164-171(2002).

18）古閑聡美, 落合信恵, 浅尾明美, 野村真澄, 本郷 陽子, 島田玲子, 副島秀久, 血液透析患者の教育 指導のあり方を考元る, 日本透析療法学会雑誌, 25, 1369-1372(1992).

19）石原ミ交子, 重松京子, 㪰田美紀子, 落合美登子, 黒川孝子, 竹内順子, 伊藤ち上子, 保科良子, 桑 田有希子, 服薬コンプライアンスに関する実態調 査, 善仁会研究年報, 18, 46-48(1997)． 